\title{
Protection of Investors and Credit Rating Agencies Regulation in Latin America ${ }^{1}$
}

\author{
Márcio Ferro Catapani \\ Federal University of São Paulo, São Paulo, Brazil \\ Email:marciocatapani@hotmail.com
}

How to cite this paper: Catapani, M. F. (2018). Protection of Investors and Credit Rating Agencies Regulation in Latin America. Beijing Law Review, 9, 547-563. https://doi.org/10.4236/blr.2018.94032

Received: April 22, 2018

Accepted: September 22, 2018

Published: September 25, 2018

Copyright $\odot 2018$ by author and Scientific Research Publishing Inc. This work is licensed under the Creative Commons Attribution International License (CC BY 4.0).

http://creativecommons.org/licenses/by/4.0/

\begin{abstract}
The growth and expansion of economies of developing countries rely, in a great extension, on the access to financing sources for entrepreneur activities. Capital markets are one of the most efficient alternatives for local companies to have access to capitals, either local or foreign, and, therefore, for the boosting of the economic progress of such countries. In this sense, a legal framework of capital markets that fulfill the requirements of stability, certainty and security are essential in order to countries to compete for international capitals and investments. Indeed, such requirements are imperative to grow an environment of confidence of investors. Among other important issues in the capital markets regulation scope, there are two that have a vital importance to induce the confidence of investors and, consequently, to attract investment: the legal protection of investors and the regulation of the activities of credit rating agencies. It is vital that the legal system sets a framework for the protection of investors in the capital markets. The need of a stable, clear and secure framework does not imply an excessive intervention of the state in the ability of private economic agents to regulate their own interests. On the contrary, the state shall only provide for the minimum content of the financial services agreement and assure the compliance of the obligations taken under a contract. Furthermore, as the investment decisions made by economic agents rely mostly on the information they have on the financial instruments that are offered in the market, rules determining the full disclosure of information are essential. Concerning credit rating agencies, it is important to understand the role that such entities have undertaken in capital markets. Information about companies and financial instruments is the material economic agents use to make their investment decisions. But the cost to process and analyze the whole bunch of available data is too high for most
\end{abstract}

\footnotetext{
${ }^{1}$ This paper is part of a broader research project regarding capital markets in Latin America. The Uniform Law Review published a first article on the subject (Catapani, 2013 Capital Market Law in Latin America: An Overview. Uniform Law Review, Unif. L. Rev., Vol. 18, 2013, 201-224).
} 
agents, so they have to rely on the opinion of experts, such as credit rating agencies. In this context, regulation shall assure that the aforementioned agencies act in a fair and transparent way. Rules concerning conflict of interests, publicity of the criteria of rating analysis, and supervision on the activities of agencies are important to the growth of a sound capital market and an investment friendly environment. The article will focus on some of the production-centered jurisdictions-Argentina, Brazil, Chile, Colombia, Mexico, and Venezuela. They were chosen because they are the major economies in the region.

\section{Keywords}

Capital Markets, Capital Markets Law, Investors' Protection, Credit Rating Agencies, Latin America

\section{Introduction}

The growth and expansion of economies of developing countries rely, in a great extension, on the access to financing sources for entrepreneur activities. Capital markets are one of the most efficient alternatives for local companies to have access to capitals, either local or foreign, and, therefore, for the boosting of the economic progress of such countries. In this sense, a legal framework of capital markets that fulfill the requirements of stability, certainty and security are essential in order to countries to compete for international capitals and investments. Indeed, such requirements are imperative to grow an environment of confidence of investors.

In the present globalized economy, which is characterized by a large computerization of the financial systems, the demand for financial instruments and the asset price formation ${ }^{2}$, specially of those assets which are not essentially material, depend largely not only on the profit they can actually generate to the economic agents, but also, in a great extent, to the expectation of profit that they arouse. Such expectation has a deep connection to the confidence that legal frameworks and local institutional environments ${ }^{3}$ can build up in investors ${ }^{4}$.

\footnotetext{
${ }^{2}$ According to Max Weber, "For the development of a wholesale trade carried out in such fashion, and specifically for speculative trade, the indispensable prerequisite was the presence of an adequate news service and an adequate commercial organization" (Weber (1947) General Economic History.Glencoe, Illinois: The Free Press, p. 294).

${ }^{3}$ On the other hand, the lack of confidence affects negatively the demand and the price of financial assets. For instance, concerning the Brazilian public bonds market, André Soares Loureiro and Fernando de Holanda Barbosa affirm that "the repeated government interventions in economy, impacting already firmed agreements; and the macroeconomic imbalances that characterized the first half of the 1980's led the economic agents to charge increasing risk premiums in the acquisition of federal public bonds" (Loureiro \& Barbosa (2003). Dívida Pública e Prêmio de Risco dos Títulos Públicos no Brasil. Série Notas Técnicas do Banco Central do Brasil, 42, p. 14. Available at

http://www.bcb.gov.br/pec/NotasTecnicas/Port/2003nt42DividaPubPremioRisco_TPBp.pdf. Access

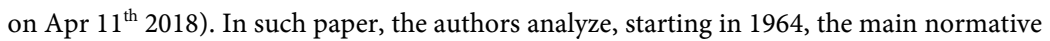


In this sense, for instance, Manuel Castells says:

Two key factors appear to be at work in the valuation process: trust and expectations. If there is no trust in the institutional environment in which value making operates, no performance in profits, technology, or use value (for example, energy resources) will translate into financial value. On the other hand, if there is trust in the institutions underlying the market, then expectations of the potential future value of a future stock will increase its value. ${ }^{5}$

Investors who allocate their assets and investments not only in their original jurisdiction-the so-called international investors-tend to seek for reliable places to direct their money ${ }^{6}$. In this competition of jurisdictions and economic systems for capital, developed countries seem to have an initial advantage: their legal frameworks and institutional environments tend to be better-known and there is a common psychological feeling that they are more reliable. In other words, if developing countries-such as the Latin American ones-want to benefit from international capital to the expansion of their own capital markets, they have to make an additional effort in order to stablish a system ${ }^{7}$ that builds up confidence in both international and domestic investors.

and operational changes in the Brazilian public bonds market and their consequences on the acceptance of such bonds, and the debt evolution. They infer that "During the 1980's and the beginning of the 1990's, the debt composition changed several times due to the economic situation and a sequence of failed stabilization plans. In fact, its maturity profile has been progressively reduced. The short debt maturity and the uncertainty that marked this period eroded the confidence of private agents in the government's ability to meet its intertemporal restraint, inducing them to demand increasing risk premiums, which increased the cost of debt financing, accelerating its growth" (idem, pp. 26-27). It is also important to keep in mind that, besides the enhancement of such funding mechanism, the lack of confidence by economic agents leads to a minor incentive to the allocation and maintenance of capital in the public bonds market, in view of the high risk profile that such assets acquire, in order to exclude several segments of investors.

${ }^{4}$ In the United Kingdom, the Financial Services and Markets Act of 2000-which is not in force anymore-expressly listed market confidence as one of the aims to be pursued by the former Financial Services Authority-presently replaced by the Financial Conduct Authority and the Prudential Regulation Authority. Therefore, there was an express rule determining that, in such legal system, the market confidence goal should guide all the activities (either regulatory or administrative), including rulemaking and market supervision related to capital markets. Even in other legal systems, such goal is an implicit prerequisite for the development and maintenance of financial instruments structured markets.

${ }^{5}$ Castells (2010) The Information Age: Economy, Society, and Culture. Malden, Massachusetts: Wiley-Blackwell, p. 159. As Castells demonstrates, trust and expectations are intrinsically linked elements, for the first results in the second-or, more precisely, results in a positive expectation. Such need for trust, which in legal terms is usually referred to as certainty or legal certainty, is one of the core issues of commercial law. In the words of Paula Forgioni, "this is another trigger of commercial law: the greater the level of legal certainty and predictability provided by the system, the more flowing are economic relations. The relation between certainty, predictability and the functioning of the system, explained by Weber and the basis of the thinking of modern jurists, is a determining factor of the very genesis of commercial law" (Forgioni (2003) A interpretação dos negócios empresariais no novo Código Civil brasileiro. Revista de Direito Mercantil, Industrial, Econômico e Financeiro, XLII (130), abr.-jun. 2003, p. 12).

${ }^{6}$ In the opposite sense, domestic investors tend to send their money abroad when the economic environment in their own countries is instable and uncertain. Or, at least, they tend to invest in lower risk assets other than those of the capital markets.

${ }^{7}$ Such system is obviously not limited to the legal framework, but is also composed of social and political practices, economic institutions, cultural background, among other elements. 
Among other important issues in the capital markets regulation scope, there are two that have a vital importance to induce the confidence of investors and, consequently, to attract investment: the legal protection of investors and the regulation of the activities of credit rating agencies.

It is vital that the legal system set a framework for the protection of investors in the capital markets. The need of a stable, clear and secure framework does not imply an excessive intervention of the state in the ability of private economic agents to regulate their own interests. On the contrary, the state shall only provide for the minimum content of the financial services agreement and assure the compliance of the obligations taken under a contract. Nevertheless, considering that the financial services agreement is a contract of adhesion or standard form contract, there shall be rules to prevent unfair practices. However, the definition of unfair practices and their consequences shall not be left at the sole discretion of public authorities, otherwise an environment of legal instability, which is able to discourage investment, may arouse.

Furthermore, as the investment decision made by economic agents rely mostly on the information they have on the financial instruments that are offered in the market, rules determining the full disclosure of information are essential.

Concerning credit rating agencies, it is important to understand the role that such entities have undertaken in capital markets. Information about companies and financial instruments are the material economic agents use to make their investment decisions. But the cost to process and analyze the whole bunch of available data is too high for most agents, so they have to rely on the opinion of experts, such as credit rating agencies. In this context, regulation shall assure that the aforementioned agencies act in a fair and transparent way. Rules concerning conflict of interests, publicity of the criteria of rating analysis, and supervision on the activities of agencies are important to the growth of a sound capital market and an investment friendly environment.

In the following discussion, this article will focus on some of the production-centered jurisdictions-Argentina, Brazil, Chile, Colombia, Mexico, and Venezuela ${ }^{8}$. They were chosen because they are the major economies in the region. https://www.sunaval.gob.ve

\section{Protection of Investors}

Protecting consumers of financial services and products is a condition to the full

\footnotetext{
${ }_{8}^{8}$ In order to seek for accurate and updated data, all information concerning the rules in force in each jurisdiction was obtained from the official websites of the local securities regulators, that means: Argentina: Comisión Nacional de Valores (2018) <http://www.cnv.gob.ar/>; Brazil: Comissão de Valores Mobiliários (2018) <http://www.cvm.gov.br/>; Chile: Comisión para el Mercado Financiero (2018) $<$ http://www.cmfchile.cl/portal/principal/605/w3-channel.html $>$; Colombia: Superintendencia Financiera de Colombia (2018) <https://www.superfinanciera.gov.co $>$; Mexico: Comisión Nacional Bancaria y de Valores (2018) <https://www.cnbv.gob.mx $>$; and Venezuela: Superintendencia Nacional de Valores $(2018)<$ https://www.sunaval.gob.ve $>$. Unfortunately, the website of the Venezuelan Superintendencia Nacional de Valores has been out of service for many times, so information was obtained from the website of the Caracas Stock Exchange (2018) <https://www.bolsadecaracas.com $>$.
} 
development of capital markets. Indeed, such protection raises the level of investors' confidence and is an incentive to the allocation of resources in securities-which are, by definition, risky assets and depend deeply on reliability.

The regulation concerning protection of consumers usually focuses on three mains aspects: 1) full disclosure, to allow a more secure and fact-based investment decision and to reduce the actual gap of information among market agents, 2) prohibition of any sanctions to unfair practices, and 3) regulation of the financial services agreement.

\subsection{Argentina}

As to full disclosure, Law n. 17.811/1968 establishes the committal of making public periodical financial statements, and, previously to general meetings, other relevant information (sections 64 and 71, respectively).

Additionally, Federal Decree n. 677/2001 sets transparency requirements for public offerings and governs 1 ) the publication of relevant information (Section 5 and Section 6 ); 2) the duty of self-regulated institutions to mantain control mechanisms (Section 10); 3) the duty of trading systems to assure the full application of principles of investors protection, equity, and efficiency (Section 11);4) the limits for people who act in public offerings to acquire the offered securities (Section 16 and Section 17); 5) the publicity and advertisement of public offerings (Sections 18 to 21); and 6) the definition and legal consequences of violations of the publicity duty of public offerings and other related species of misconduct (Sections 33 to 37).

Concerning unfair practices, Law n. 17.811/1968 sets forth the legal sanctions that may be applied and the administrative procedure to impose such penalties (Sections 10 to 15). Self-regulated institutions may also apply disciplinary sanctions to their participants (Sections 59 to 62)

Law n. 17.811/1968 has also a few provisions on financial services agreement. The stockbrokers must keep secrecy regarding the operations they perform for their clients and can accept orders only from previously identified clients (Section 46). Moreover, the fees that brokers can charge are regulated, and limited to the amount fixed by the stock exchange and approved by the government (Section 50 and Section 51).

Finally, the Mercado de Valores de Buenos Aires has enacted a self-regulatory conduct code in March 2009, focusing on investors' protection. Such code has rules related to 1) the opening of accounts for clients by brokers, 2) rights of consumers against brokers, 3) transparency and secrecy duties, and 4) receiving complaints. The code also regulates some market transactions.

\subsection{Brazil}

Brazilian disclosure primary rules are set forth in the Corporations Act (Law n. 6.404/1976). In fact, Section 157, $₫ 4$, of such Act establishes that public companies officers shall publish and inform to the stock exchange all facts that may af- 
fect the price of securities. The financial statements must also be made public by all share companies (Section 176, § 1). Regulation (Instrução) n. 358/2002 of the Comissão de Valores Mobiliários details the duty of making information public and states that a break of such task is a major infraction (Section 18).

Law n. 6.385/1976 specifies which sanctions can be imposed to transgressors in case of unfair practices and other kinds of misconduct (Section 11). However, the definition of infractions is delegated to the Comissão de Valores Mobiliários. According to such Law, it is possible to the Comissão to make a bargain with the defendant, if the later ceases the illegal conduct, fix all irregularities and pay a due compensation. The Law also contains procedural rules for the suit that will take place before the Comissão (Section 9).

The Comissão de Valores Mobiliários has enacted several regulations defining unfair practices and kinds of market misconduct. The most important is Regulation n. 491/2001, which lists 15 major infractions. But other rules dealing with specific matters complement the mentioned one ${ }^{9}$.

Market manipulation, insider trading and non-authorized performance of market activities are criminal offenses (Law n. 6.385/1976, sections 27-C to 27-E).

Rules concerning financial services agreement are gathered in Regulation $\mathrm{n}$. 505/2011 and cover 1) the brokers' burden of keeping a clients record; 2) the transmission of orders to the broker, including electronic orders; 3) the execution of clients' orders; 4) the need of client identification; 5) the transfer of transactions among brokers and other market agents; 6) the payment and receipt of values; 7) duties of good-faith, diligence and loyalty; and 8) species of prohibited conduct.

In 2006, Brazilian Supreme Court decided that the Consumers Protection Code applies to relationships in financial markets, which also includes services in capital market and the relationship between brokers and their clients. In that same occasion, the Supreme Court decided that Administrative agencies-such as the Central Bank or the Comissão de Valores Mobiliários-do not have power to enact rules concerning directly protection of consumers, which brought up some degree of uncertainty relating the application of some regulations.

\subsection{Chile}

In Chile, the Securities Market Act (Ley del mercado de valores) states disclosure duties: all issuers and other agents submited to the regulation set by Comisión para el Mercado Financiero ${ }^{10}$ must make public all essential fact or information regarding themselves or their business as soon as they are aware of it (Section 10 and Section $7, \S 2$ ). The Comisión may regulate such general rule and define the

\footnotetext{
${ }^{9}$ See, for instance, Regulations n. 323/2000 and 505/2011.

${ }^{10}$ The Comisión has substituted the previous Superintendencia de Valores y Seguros de Chile.

${ }^{11}$ According to the section 3, $\$ 8$, of the Comisión para el Mercado Financiero de Chile Organization Act, the information shall be true, enough and opportune on the legal, economic and financial situation of the supervised entities.
} 
kind of information that must be disclosed to the market. The information must be true and complete $\left(\right.$ Section $65^{11}$ ). Insider trading prohibition is set in Sections 164 to 172 .

The Act also defines some sanctions that can be imposed to market agents (Section 58). Sections 59 to 61 establish that some practices are criminal offenses, and Section 52 and Section 53 forbid market manipulation and simulation of transactions and prices. Additionally, penalties and procedural rules are included in the Comisión para el Mercado Financiero de Chile Organization Act $^{12}$ (Titles III and IV, Sections 35 to 71).

Tha same Act has some rules regarding securities consumer protection too. Section 1 of the Act provides that the regulation enacted by the Comision shall keep a general and systematic approach to the market, taking into consideration specially the interests of investors and consumers of insurance products. The Comisión has the power to forbid, for a period up to 3 months, the supervised entities to perform market transactions whenever their financial situation can jeopardize assets of obligations with the investors (Section $5, \$ 26$ ). In case of serious brake of regulations or legal provisions, the Comisión can also impose the discontinuation of the activities of supervised entities (Section 21, \5). The Comité de Autorregulación Financiera, a self-regulation body created by the same Act, shall also pursue the protection of investors (Section 72 and Section 76).

The intermediation of securities is also regulated in the Securities Market Act. Section 34 makes brokers and dealers responsible for the identity and regularity of their clients and for the integrity of the traded securities. Such market agents must also define a contractual framework to govern their relationship with their clients, including rules concerning data management, and acceptance and refusal of orders (Section 33). Such contractual framework must accomplish with the minimum standards fixed by the Comisión.

\subsection{Colombia}

Decree n. 2.555/2010 imposes to issuers the obligation to publish all relevant information related to them and the securities they issue. Relevant information is defined as any fact that may affect an investment decision and the Decree provides an illustrative list of such kind of data (item 5.2.4.1.5).

Law n. 964/2005 creates the Integral Information System of the Securities Market (Sistema Integral de Información del Mercado de Valores-SIMEV), which records and publishes data of all issuers and intermediaries (Section 7, $₫$ 2). Such Law also creates the position of contralor normativo, an independent officer of brokers who is in charge of assuring the compliance of the broker's activities with laws and regulations; and the fulfillment of transparency, disclosure, and ethical duties (Section 21).

Law n. 964/2005 also defines some infractions (Section 49 and Section 50), es-

${ }^{12}$ Decreto Ley n. 3.538/1980, as amended by Law n. 21.000/2017. 
tablishes the respective sanctions (Sections 51 to 57), and fixes procedural rules (Sections 58 to 62).

Finally, Decree n. 2.555/2010 regulates the following kinds of financial services, among others: securities administration, clients' portfolio administration, financial advising, and brokerage (itens 2.9 .6 to 2.9.9). Regarding securities administration, for instance, item 2.9.6.1.3 sets the responsibility of the administrator even in case of light negligence, its obligation of reinvesting profits or, if it is not possible, making them available to clients immediately, and the duty of monitoring capital and yields.

Item 2.9.20.1.1 submits brokers to a secrecy rule about their clients' data and transactions, and forbids brokers to advise or perform orders that may arise to their clients an unusual risk, unless the later authorizes the former in writing and expressly agree with such risk.

Law n. 964/2005 has a Title named Investors Protection System (Sections 38 to 48). However, its rules focus on issuers' corporate governance and not capital markets regulation itself.

\subsection{Mexico}

Section 2, VII, of Mexican Securities Market Act defines relevant event as the one which can affect the price of a security and gives the Comisión Nacional Bancaria y de Valores power to set examples of relevant events. Section 2, XII, on the other hand, defines relevant information as all data needed in order to precise the issuers' present and actual situation, including matters related to the economic group it may belong, and that can affect the price of its securities. Relevant information and events shall be made public, according to the terms of Sections 104 and 105.

Insider trading, dissemination of false information, market manipulation, and simulated transactions are considered to be infractions (Securities Market Act, Sections 362 to 370). Some other kinds of conduct are classified as crimes (Sections 373 to 387). The species of administrative sanctions (Sections 392 to 395) and procedural rules are also stated (Sections 389 to 391, and 396 to 398).

Regarding the relationship between consumers and intermediaries, section 4 of the Act sets a generic liability rule: legal transactions that break any of the Act's rules bring out the obligation to indemnify. Brokers cannot promise profits nor undertake to afford potential losses (Section 188). Moreover, brokers are responsible for the integrity and authenticity of the securities they trade (Section 189), and they also shall properly identify their clients (Section 190) and keep the later informed about all applicable fees (Section 191).

Sections 192 to 198 focus on protection of investors, setting secrecy, diligence and fiduciary duties. Lastly, Sections 199 to 204 provide the legal framework for the securities intermediation agreement.

\subsection{Venezuela}

In Venezuela, the new Securities Market Act (Decreto n. 2.176/2015) has a Title 
that governs the so-called "Citizen participation and advocacy, and investors protection" (De la participación y defensa ciudadana y de la protección a los inversores) (Sections 87 to 93), which sets some corporate governance rules, as well as dispositions concerning citizens independent boards (consejos de protección del inversionista) that may syndicate public companies and seek for the protection of investors (Section 87). A general interventional principle is stablished, by which the Superintendencia Nacional de Valores may "adopt measures of protection of investors against the controller shareholder" (Section 93, \$3).

Concerning transparency and publicity, a disclosure principle is established in Section 61, by virtue of which issuers have to provide investors with all information required by the Superintendencia Nacional de Valores and to make public all relevant facts that may influence somehow the price of securities. Before being public, the information is considered to be privileged and its use is restricted (Section 70).

Such Act has provisions concerning infractions and sanctions too. Sections 117 to 133 regard administrative sanctions. Section 117 describes only two kinds of them: fines and revocation of the authorization to operate in the market. Nevertheless, Section 121 list ten different "administrative measures" that can be imposed by the Superintendencia, such as stop orders, imposition of capital reposition, prohibition to perform new transactions, and immediate cessation of publicity. However, the last item of such list has an open provision enabling the Superintendencia to "take any other [measure] that is necessary to mend administrative, technical, legal, economic or financial situation" (Section 121, 10). With the same scope, the President of Venezuela, with the Ministers Council, has the power to "suspend operations in the capital market, whenever he consider it is convenient to safeguard the economy of the country" (Section 2).

Sections 145 to 149 define criminal offenses, which include insider trading and provision of false information to the market and public authorities.

Liability for damages is mentioned in Section 121 and falls in the general rule that any person whose acts may cause harm to another shall pay due compensation $^{13}$.

There is no detailed regulation of the financial services agreement. However, the Caracas Stock Exchange Negotiation Rules sets some rules related to this matter, such as the ones regarding investors' identification (Sections 27 and $28)^{14}$, and kinds of orders (Sections 35 to 39 ).

\subsection{Discussion}

All the relevant jurisdictions have a more or less detailed set of rules dealing with the main analyzed issues, e.g., 1) full disclosure, 2) prohibition of and sanctions to unfair practices, and 3) regulation of the financial services agreement.

Market transparency and enforcement of rules protecting investors are vital in

\footnotetext{
${ }^{13}$ This conclusion is confirmed by section 21 of the Caracas Stock Exchange Regulation, which states: "the liability of the members of the stock exchange follows the general rule standards".

${ }^{14}$ See also sections 18, $e$, and 21, a, of the Caracas Stock Exchange General Regulation.
} 
order to seek for foreign investments in a competitive and globally integrated market. They have an even greater importance in emerging markets, because investors tend to be more confident in dealing in markets already well developed-and, consequently, well known. This natural barrier and its cultural component can be overcome only if the emerging jurisdiction can assure foreign investors that it is safe to have local securities and that any misconduct will be avoid and punished-in other words, that the investment risk is not so high. Such confidence, of course, cannot be achieved at once, but a proper framework is an important step towards it.

Full disclosure shall comprise two main sets of information: regular and periodic data of the issuer and its financial statements, and relevant facts that may affect securities prices. In both cases, non-compliance with disclosure requirements shall arise sanctions, either administrative or criminal-or both. In all the relevant jurisdictions, proper disclosure rules are established, although the correspondent sanction may vary. As there is a significant and sufficient functional convergence, no reformulation or further harmonization seems to be essential to either regional integration or attracting foreign investment.

Presently, new transparency concerns are arising in a global level, such as the ones related to the remuneration of directors and officers. The emerging markets-including the Latin American jurisdictions-have to take part in this debate and constantly adapt to the new market demands. Actually, such demands represent a great opportunity to emerging markets, which can run ahead and build a reputation of protecting investors.

On the other hand, it shall be kept in mind that consumers protection rules result in additional costs to financial services providers-costs that, at the end of the day, will be paid by investors. Thus, clear and stable rules are essential to enable cost projections and economic calculation.

Defining infractions is also an essential feature of capital market legal framework. As the ultraliberal model has already been overcome, and it is widespread acknowledged that a completely free market is unfeasible, the State intervention to restrain and punish misconduct and unfair practices is an important parcel of capital market regulation. Nonetheless, infractions and penalties shall be set forth in a precise and stable way, otherwise legal uncertainty - and the inevitable lack of confidence that follows it-will arise. The main legal instruments to avoid such undesirable uncertainty are the legal types technique and the principle nulla poena sine praevia lege. The combination of both principles means a restraint of the powers of Securities and Exchange Comissions, which also leads to the necessity of a constant attention and adaptation of legal rules to market practices. Although the idea that Comissions must have full powers to prevent abuses seems to meet the need for investors protection, it may cause the opposite effect, for it increases the level of instability and lack of confidence, specially if the Comissions' proceedings may be understood as politically directed. Moreover, a temperate regulatory authority is a positive signal to market agents. In this 
specific field, some efforts to seek harmonization and to raise legal standards should be made by some jurisdictions, in order to establish a clearer set of illegal practices and the penalties they may arise.

Lastly, rules governing financial services agreement shall focus on the aspects of the relationship between client and services provider that are directly affected by their different level of economic power and expertise. In fact, consumers usually have no choice other than adhering to the model agreement offered by the services provider, who is in position to impose all the relevant clauses of such agreement. Consequently, state rules shall assure that the services provider does not include in the instrument abusive or unfair terms. For instance, a key point regarding this issue is the liability of the provider for improper or defective services. On the other hand, a clear definition whether general rules on consumers' protection apply to this kind of services is crucial. Even so, aspects of the financial services relationship that do not fall directly in the scope of the different level of economic power and expertise shall be left to the parties' private autonomy.

Concerning this matter, although to some degree all jurisdictions have rules governing such agreement, they have a rather different approach to it, and harmonization is advisable to achieve an effective regional integration. In particular, a major difference that can be underlined is the excessive level of discretion of public authorities in Venezuela to consider a violation of market rules and consequently to impose administrative measures, which may create an environment of uncertainty unfriendly to private investments.

\section{Rating Agencies Regulation}

It is unequivocal that credit rating agencies ${ }^{15}$ perform a highly significant role in capital markets nowadays. As said before, their activity is essential to reduce the costs of credit risk analysis, to set some objective patterns that allow the assessment and comparison of credit financial instruments, and to draw a control line for the allocation of resources by institutional investors that act as agents for the interests of others.

Their rates influence tense markets in a decisive way, to the point of making some securities or investments financially unviable. The more significant such role is, the more inflamed the debate on the desirability of the regulation of rating agencies' activities becomes. Indeed, the influence of such financial services providers has driven some governments to regulate their activities. After all, some experts criticize this attitude because it may seem, especially to investors that are less used to market practices, that a valuation made by a regulated and registered rating agency is an official recommendation to invest or not in an as-

${ }^{15}$ According to the Code of Conduct Fundamentals for Credit Rating Agencies published by IOSCO in 2015, “'Credit rating agency' or 'CRA' means an entity that is in the business of issuing credit ratings". And “'Credit rating' or 'rating' means an assessment regarding the creditworthiness of an entity or obligation, expressed using an established and defined ranking system" (International Organization of Securities Commissions-IOSCO (2015). Code of Conduct Fundamentals for Credit Rating Agencies. Available at https://www.iosco.org/library/pubdocs/pdf/IOSCOPD482.pdf access on May $3^{\text {rd } 2018) . ~}$ 
set. In addition, the widespread use of ratings would decrease the level of care taken by institutional investors based on their own analysis and could, therefore, have undesirable effects ${ }^{16}$.

\subsection{Argentina}

Law n. 23.697/1989, Section 41, empowered the Argentinean Government to set rules regarding capital market in order to seek for its full and fair development. Based on this premise, Federal Decree n. 656/1992 was enacted to regulate the activities of rating agencies ${ }^{17}$.

As a general rule, securities issuers are not compelled to submit the assets they offer in the market to a rating agency. Such kind of risk valuation is an option, but the Comisión Nacional de Valores may impose a mandatory rating in the cases it reputes necessary doing so (Section 2$)^{18}$.

Federal Decree n. 656/1992 also creates a registry of rating agencies, which must accomplish to some requirements (Sections 6 and 10 to 12) and permanently revise their ratings. The agencies and their officers are also forbidden from developing some activities and making investments that may arise conflict of interests (Sections 18 to 20).

There are some rules stating the grades that may be granted to debt bonds (Section 13 and Section15).

The compiled rules enacted by the Comisión Nacional de Valores (Normas de la Comisión Nacional de Valores) have a whole set of very detailed dispositions concerning rating agencies (Title IX). Chapters II of such Title regulates the public universities acting as rating agencies, which are subject to a specific regulatory framework.

\subsection{Brazil}

In 2012, the Comissão de Valores Mobiliários enacted Regulation n. 521 (In-

${ }^{16}$ Frank Partnoy points out that the use of credit ratings has increased even though they have proved not to be entirely precise or reliable - the so-called "rating paradox"-by virtue of the regulation that, in many cases, imposes their use for institutional investors. In this context, it is crucial that institutional investors resort not only to credit ratings to make their investment decisions (Partnoy, (2009), Rethinking Regulation of Credit Rating Agencies: An Institutional Investor Perspective (July 6, 2009). Council of Institutional Investors, April 2009; San Diego Legal Studies Paper No. 09-014. Available at SSRN: https://ssrn.com/abstract $=1430608$, access on May $3^{\text {rd }}$ 2018). See also Francesco Sangiorgi \& Spatt (2017), “The Economics of Credit Rating Agencies”, Foundations and Trends ${ }^{\circledast}$ in Finance: Vol. 12: No. 1, pp 1-116. Available at:

http://dx.doi.org/10.1561/0500000048, access on May $3^{\text {rd }} 2018$.

${ }^{17}$ Federal Decree n. 656/1992 was amended by Federal Decree n. 749/2000.

${ }^{18}$ Before the amendment mentioned in the previous footnote, issuers would have to present 2 risk rates in order to register an offering. The reasons of such modification are exposed in the Consideranda of Federal Decree n. 749/2000: "CONSIDERANDO: (...) Que en los mercados de capitales de otros países es facultativo de las emisoras el requerir los servicios de las sociedades calificadoras de riesgo, lo que torna necesario adaptar nuestra normativa a fin de no imponer a los emisores de nuestro mercado cargas superiores. Que por tanto, se estima procedente eliminar la obligatoriedad del requisito de la previa presentación de DOS (2) calificaciones de riesgo, para conceder la autorización de oferta pública." 
strução n. 521/2012), which for the first time brought out a complete set of rules regarding the activities of rating agencies in Brazil. According to such Regulation, a rating agency must be either registered or recognized ${ }^{19}$ in order to perform credit or issuers ratings in Brazil.

The agencies shall avoid the drafting of any rating that may contain false statements, or is able to mislead market agents about the situation of an issuer or a financial asset. Besides that, the information shall be written in a simple, clear, concise and objective language (Section 10).

The Regulation stablishes some requirements for rating reports: they must follow the proceedings and methodology adopted by the agency, and shall evidence information such as, for instance, the relevant information sources upon which they are based; the officers in charge of the rating; the dates of the first rating and of its last update; the frequency of updating; any limitation of the analysis performed by the agency; and potential situations of conflict of interests (Section 16). Moreover, the Regulation provides for some examples of conflict of interests: in case the issuer or any related part responds for more than $5 \%$ of the agency's annual revenue; the agency, its officers, the persons who worked in the rating issuance, or any person related to the aforementioned have financial or commercial relevant interest in the assessed entity; or either the agency officers or any person who worked in the rating issuance have any relation with someone that works for the assessed entity (Section 16, $₫ 2$ ). There is not a prohibition to act in conflict of interests, only the duty to clearly and ostensibly disclosure the conflictual situation.

Credit rating agencies shall also perform their activities keeping up with honest, good faith and ethical standards, and are obliged to have a code of conduct (Section 19), which minimal content is explicated by Regulation n. 521 (Section 20). The code of conduct shall be compatible with the Code of Conduct Fundamentals for Credit Rating Agencies of the International Organization of Securities Commissions-IOSCO.

Furthermore, the credit rating agency has to develop and make public a remuneration policy, which must comprise the criteria for the performance evaluation of its officers (Section 27). An internal system of risk segregation is mandatory (Section 28).

Finally, the Regulation sets forth a fine penalty in case of not fulfillment of some of the duties imposed to the agencies (Section 33 and Section 34).

\subsection{Chile}

In Chile, risk classification is governed by Title XIV of Law n. 18.045/1981 (Sections 71 to 95). In order to be authorized to perform their activities, rating agencies must enroll with a specific public registry and fulfill some general requirements (Sections 71 and 72, respectively). The Comisión para el Mercado Finan-

${ }^{19} \mathrm{An}$ agency incorporated under Brazilian laws is subject to the registry proceedings; a foreign agency must be recognized by the Comissão. 
ciero de Chile has the legal power to develop such general rules and to supervise rating agencies.

Debt bonds issuers must contract at least two rating agencies permanently $y^{20}$, whereas the risk classification is optional to equity issuers and investment funds (Section 76). One specific agency may be assigned by the Comisión (Section 77).

Section 79 establishes some conditions to officers of agencies and Sections 81 and 82 set conflict of interests rules. There is also a revenue concentration limit: no more than $15 \%$ of an agency's revenue can come from one issuer or economic group (Section 82-bis). The duty of care and diligence is imposed to all people and institutions involved in classification activities (Section 93).

Moreover, Law n. 18.045/1981 sets forth rates and criteria of debt bonds classification (Section 88) and also establishes the grades that can be granted to equities and investment funds (Section 91).

\subsection{Colombia}

In Colombia, by virtue of Law n. 964/2005, risk classification is taken as a capital market activity (Section 3, g). The Government has the legal power to regulate such activity, in special to establish which intermediaries, issuers and collective schemes must submit to rating. Moreover, such rating shall be public (Section 4 , 1).

There are restrictions that ought to be observed by rating agencies and their officers, set forth in Section 20, $\$ 4$ of Law n. 964/2005, and in Decree n. $2.555 / 2010$. The later has detailed rules on the agencies' activities and on the uses that can or shall be made of ratings. For instance, it states the possible kinds of classification (item 2.22.1.1.3), the securities that have to be rated (item 2.22.1.1.4), and conflict of interests rules (item 2.22.1.1.6 and 2.22.1.1.9).

\subsection{Mexico}

Sections 334 to 341 of the Securities Markets Act govern rating agencies in Mexico. They must hold a governmental authorization that cannot be transmitted (Section 334). The Act sets conflict of interests rules (Sections 337 e 338) and the duty of making the ratings public (Section 339).

The general regulations on brokers and dealers (Circular única de casas de bolsa) and on investment companies (Circular única de sociedades de inversión) make several references to ratings and investment grades related to portfolio requirements.

\subsection{Venezuela}

In Venezuela, the Securities Market Act of 2015 includes credit rating agencies within the persons subject to control by the Superintendencia Nacional de Valores (Section 3, item 12). The Superintendencia may enact rules that apply to the agencies' activities (Section $3, \S 1$ ).

\footnotetext{
${ }^{20}$ Short-term debt bonds may require the hire of just one agency's services.
} 
Such Act defines credit rating agencies (Section 34), but does not bring out other dispositions on their activities. Section $145, \S 3$, considers a crime the issuance of a rating with the purpose to manipulate the market, aiming some kind of profit.

More detailed rules are set forth by Resolution n. 334/1994 of the former Comisión Nacional de Valores. It provides the conditions that agencies must fulfill to be granted the necessary authorization (Sections 5 to 7).

According to such Resolution, debt bonds offerings must be preceded by two rating evaluations (Section 4). Additionally, it sets conflict of interests rules (Sections 8 to 11) and establishes grades and criteria to debt bonds classification (Section 19 and Section 20).

\subsection{Discussion}

A first issue related to the activities of rating agencies is whether there is need for its regulation. As said above, for some experts, a widespread adoption of ratings in regulation may arise the feeling that such classifications are official and somehow guaranteed, and may also disincline a more accurate and diligent risk analysis by institutional investors.

Although such concerns are true to some extension, there are some fair uses of ratings that regulatory bodies cannot fail to see and deal with-and sometimes such uses do not depend on their will. Inexperienced and less informed investors do not have the same ability, expertise, resources, and time as rating agencies to analyze issuers' data. Consequently, it is not completely undesirable that single investors use ratings as a guide to their investment decisions. Likewise, external ratings may be an important additional source to risk assessment of institutional investors. In both cases, the main goal of regulators must be to assure that the rating activity is developed in a fair and transparent way, and that investment decisions are not made taken ratings as the only source of information.

Furthermore, the fact that, nowadays, ratings are a settled market practice makes regulation essential, in order to avoid abuses and unfair conducts. Rules preventing conflict of interests and sanctions in case of inappropriate behavior are necessary to avoid deleterious effects of rating agencies' activities. The regulatory frame must be designed in such a way that, on the one hand, reduces as much as possible the perception of officiality of ratings and, on the other hand, it punishes misconduct and raises the degree of care and diligence of rating agents.

In this context, some basic rules are advisable, such as: 1) a registry of rating agencies; 2); requirements of expertise and responsibility for officers and employees; 3) conflict of interest rules; 4) principles of transparence and of the need to update ratings; 5) sanctions for misconduct. Another issue that should be regulated in order to prevent legal uncertainty, at least on the principles level, is the civil liability of rating agencies for the results of its activities-either to impose such liability or to lay it off clearly.

Detailed rules regarding possible grades and specially rating criteria shall be 
avoided, since they transmit a strong sense of officiality of the rating agencies' activities and discourage the search for other information sources. Moreover, the use of ratings as only source by institutional investors must be forbidden and internal analysis shall be imposed. Finally, the hiring of a rating agency shall be an option of the issuer and not a legal requirement, otherwise the undesirable feeling of officiality of ratings will increase.

\section{Conclusion}

Even though Latin America countries cannot be considered a completely homogeneous group, and they enjoy different levels of institutional and legal development of capital markets, it is possible to conclude that all the jurisdictions taken into consideration demonstrate a concern and a commitment to cultivate an efficient mechanism for corporate funding through capital markets.

All jurisdictions have set forth a legal framework to protect investors in capital markets and to regulate the activities of credit rating agencies that fulfill the minimum requirements for the attraction of international capitals and assets. Nonetheless, the success of such strategy depends not only on the existing legal rules-and their quality-but also on the maintenance of a culture of respect for investment and on the development of a business environment in which there are not excessive intervention of the State in the markets.

Once more, it is essential to underline the core role that the confidence of investors plays in enabling the growth of capital markets. And, within this scope, there is still a long way for such countries to go through in order to reduce the gap that exists among them and the most developed countries in the attraction of capitals.

\section{Conflicts of Interest}

The author declares no conflicts of interest regarding the publication of this paper.

\section{References}

Caracas Stock Exchange (2018). https://www.bolsadecaracas.com

Castells, M. (2010) The Information Age: Economy, Society, and Culture. Malden, MA: Wiley-Blackwell.

Catapani, M. F. (2013) Capital Market Law in Latin America: An Overview. Uniform Law Review, 18, 201-224.

Comisión Nacional Bancaria y de Valores (2018). https://www.cnbv.gob.mx

Comisión Nacional de Valores (2018). http://www.cnv.gob.ar/

Comisión para el Mercado Financiero (2018). http://www.cmfchile.cl/portal/principal/605/w3-channel.html

Comissão de Valores Mobiliários (2018). http://www.cvm.gov.br/

Forgioni, P. (2003) A interpretação dos negócios empresariais no novo Código Civil brasileiro. Revista de Direito Mercantil, Industrial, Econômico e Financeiro, XLII, 7-36. 
International Organization of Securities Commissions-IOSCO (2015). Code of Conduct Fundamentals for Credit Rating Agencies. https://www.iosco.org/library/pubdocs/pdf/IOSCOPD482.pdf

Loureiro, A. S., \& Barbosa, F. H. (2003). Dívida Pública e Prêmio de Risco dos Títulos Públicos no Brasil. Série Notas Técnicas do Banco Central do Brasil, 42.

http://www.bcb.gov.br/pec/NotasTecnicas/Port/2003nt42DividaPubPremioRisco_TPB p.pdf

Partnoy, F. (2009). Rethinking Regulation of Credit Rating Agencies: An Institutional Investor Perspective. Council of Institutional Investors, San Diego Legal Studies, Paper n, 09-014. https://ssrn.com/abstract $=1430608$

Sangiorgi, F., \& Spatt, C. (2017). The Economics of Credit Rating Agencies. Foundations and Trends ${ }^{\circledR}$ in Finance, 12, 1-116.

Superintendencia Financiera de Colombia (2018). https://www.superfinanciera.gov.co

Superintendencia Nacional de Valores (2018). https://www.sunaval.gob.ve

Weber, M. (1947). General Economic History. Glencoe, IL: The Free Press. 